\title{
Speech Act Varieties of Chinese and Non-Chinese Community in Medan Traditional Markets
}

\author{
Vivi Adryani Nasution, \\ Niza Ayuningtias \\ University of Sumatera Utara, \\ Jl. Universitas No. 19 Kampus USU, Medan \\ vivi.adryani@usu.ac.id
}

Article History: Submitted on $4^{\text {th }}$ June 2021; Accepted 24 $4^{\text {th }}$ December 2021; Published on $30^{\text {th }}$ December 2021

\begin{abstract}
In this study focused on to describing the types and functions of the Tionghoa community utterances that tend to use Hokkien language and the non Tionghoa community that typically to use Indonesian language. The theory proposed by Austin and Leech was used to classify and analyze the speech act data delivered and collected through a non-participative observation and taking notes technique. The data were obtained from five traditional markets in Medan from July to September 2020. The data showed five kinds of speech acts from both the Tionghoa and non-Tionghoa communities. A directive speech act was the dominant speech act obtained because the directive speech act influenced the interlocutor. In this case, the customer dominated the seller to do what the customer demanded. The directive speech act also showed the chief ordering function found in the Tionghoa community, and the bargaining function was located in the nonTionghoa community. The ordering directive speech act prevalent in Tionghoa speakers related to the character of the majority of Tionghoa community members in Medan, which was straightforward. In this case, they gave orders or directly asked for what they needed or sought. Meanwhile, in the non-Tionghoa community, the utterances refer to buying and selling laws, dominated by bargaining utterances, both bargaining for goods or prices. In comparison, the declarative speech act is the minor speech act found to express resignation towards the COVID-19 condition.
\end{abstract}

Keywords: COVID-19, Medan community,speech acts, traditional market 


\section{INTRODUCTION}

Interaction of communication between humans can be done orally or in written text. Community social life is a form of social interaction in which the social interaction of the community can be seen in various locations, situations and speakers. One of the locations that can show the social interaction of the community is a traditional market. According to KBBI (Indonesia Language Dictionary), 'market is a place for people to trade and where the power of supply and demand takes place, a place for sellers who want to exchange goods or services for money, and buyers who want to exchange money for goods or services ("Kamus Besar Bahasa Indonesia (KBBI)," n.d.). Philip Kotler argues that the market contains potential customers who have certain needs in common, who are willing to carry out exchanges to obtain these needs and wants (Umaroh, n.d.). The diversity of of ethnicity, culture, language, and origin makes traditional markets significant in interaction and communication, especially in buying and selling communications (Anagaw, 2019).

In bidding, requesting, purchasing and others, there is a speech between the buyer as a speaker and the seller as an addressee that is conveyed, and there is a message or meaning contained in each speech. The speech process between speakers and addressee is a social event that involves several people speaking in a particular situation and place. This speech also makes social interactions and communication in traditional markets classified as discourse. Where discourse is an aspect of social interaction and communication is formed from an actual event (Anagaw, 2019). This speech process is a series of organized activities to achieve a goal. Speech acts are utterances carried out by speakers and addressee in social interactions. Speech acts occur in human life when exchanging messages between people (Surip, 2019). In this case, both the seller and the buyer each have a goal to be achieved through the transaction carried out.

The speech act theory originated from the linguist John Langshaw Austin and was developed by John Searle. According to Austin, speech acts are the basic functional unit of the speaker's meaning and language research. "To say something or to do something" is a short term from the speech act theory proposed by Austin (Ludwig \& de Ruyter, 2016). Based on the idea of speech acts proposed by Austin and Searle, "that the central premise of speech act theory is language construction in speech or writing, through words, sentences and interactional exchanges, conveys a speaker's underlying meaning and intention" (Ludwig \& de Ruyter, 2016). Chaer and Agustina mention that "speech acts are individual symptoms, psychological, and it is continuity is determined by the speaker's language ability in dealing with certain situations" (Sariasih, 2017). The speech act itself divides into two kinds of categories, constative and performative speech act (Bahing, Emzir, $\&$ Rafli, 2018). And he believed that people perform performative speech acts 
into three types of acts when they speak: locutionary, illocutionary, and perlocutionary (Bingtang, 2015).

Illocutionary acts are kind of speech act of doing something, have power or force which is strengthened by the meaning of a speech and expecting reactions from speech partners or called "the act of doing something" (Sagita \& Setiawan, 2020). Alston also agreed that in setting something, the speaker should use a certain "force" in speaking (Sagita \& Setiawan, 2020). Illocutionary acts are speech acts that are more varied than the other two speech acts. Illocutionary speech act activities also have more forms and functions than locutionary and perlocutionary speech acts. Searle divides illocutionary forms into 5 kinds of speech, namely assertive, directive, expressive, commissive, and declaration (Rahardi, 2009a).

These various speech acts are part of a pragmatic study. Pragmatics examines how language is used in communication and investigates a meaning as a context, not something abstract in communication (Purnamentari, Suandi, \& Wisudariani, 2019). Jacob L. Mey (1983) defined pragmatics as the study of the conditions of human language uses as these are determined by the context of society (Rahardi, 2009b). As Koutchade said, the study of pragmatics is the investigation of all aspects of meaning. These aspects come not from the formal nature of words and structures, but from the way of discourse use and how they are related to some contexts in the pragmatic field (Sagita \& Setiawan, 2020).

These definitions explain that pragmatics is also determined by the context of the situation in which the context of the situation can be divided into two, namely social and societal contexts. Social context is a context that arises because of the interaction between community members in a particular social and cultural society. Societal context is a context in which the determining factor is its position in community members in social institutions that exist in the society and culture of a particular society. The study of pragmatic meaning can be said is more subjective because pragmatic meaning contain context or pay attention to context, and each person must have their own meaning according to the context they see (Sariasih, 2017).

In this research, sellers and buyers are social and cultural members of society in Medan; hence the process (speech event) and the interactions have a social context. This implication follows what Rahardi said that speech acts are not always be interpreted as something that is implicit or implied. Involving the context of the situation can also help obtain meaning in speech (Rahardi, 2009a). It means that context helps understand the problem and the pupose of the spoken speech.

There is various research on speech acts that focus on transactions speech that has been carried out with multiple locations and objects. In which, the study also involves the social context. One of them focuses on only one type of seller's speech (Wahdian, 2016). Research also focused on the form and function of speech used by sellers and buyers in traditional markets (Padmayanti, Wedhanti, \& Agustini, 2018). Some research focused 
on sellers and buyers' speech act strategies in conventional markets. Speech act strategies for hawkers at Purabaya Terminal Surabaya City (Ziaulhaq, 2017), direct and indirect speech act strategies in Surabaya traditional markets (Astuti, 2019) and bid strategies carried out on the buying and selling process (Sari, Sofyan, \& Rochiyati S., 2020). One study was also carried out in one of the traditional markets in Medan (Surip, 2019). The thing that distinguishes research from this research is the location and purpose. The area of Surip's research was the Sukaramai traditional market, and the pursuit of his study was to determine the speech act patterns of the sellers and buyers.

According to the book "Tionghoa Medan: Komunitas Paling Kontroversial di Indonesia" stated several ethnic groups are known to be good at trading, including the Minangnesse, Bataknesse of Toba, Karonesse, and of course Chinese (Setiawan, 2018). However, that does not mean the other ethnicities in Medan are not good at trading. Different ethnicities in Medan also have the same opportunity to choose what business or occupation.

Based on these data, this research is also based on the fact that a person or a society's speech acts or language behaviour has cultural values and applies in the said community. So does Medan citizens. Medan is a city with a pluralistic society. This progress happened because Medan has various ethnic groups, customs, and languages. Each ethnic has its language that they are accustomed to using other than the Indonesian language (Nasution \& Ayuningtyas, 2020). The habit of using vernacular language can be seen in traditional markets. A marketplace is a place where various multi-ethnic communities in Medan gather. Multiple ethnicities use different languages in Medan. Hence, not only a place where buying and selling occur. A market also plays a role in bringing a linguistic phenomenon (Nasution \& Ayuningtias, 2020). And market discourse situation is primarily goal-oriented (Anagaw, 2019).

As previously stated, one of the ethnicities of which members are good in entrepreneurship, is Tionghoa. This research focuses on the utterances of Tionghoa community members that tend to use the Hokkien language frequently with people of inter-ethnicity as the interlocutors. This tendency happened because the Tionghoa community in Indonesia is dominated by Hokkian people and the Hokkian language (Nasution \& Ayuningtyas, 2020). However, it is slightly different with the non-Tionghoa community members who do not always use their vernacular language in communication regardless of communicating with people of the same ethnicity. This study also shows the diversity of vernacular language in Medan, especially Hokkien sub-ethnic in the Chinese community. This study, also shows the diversity of vernacular language in Medan, especially Hokkien sub-ethnic in Chinese community.

Other than functioning as the place for buying and selling transactions or bargaining activities, in the specific condition, a marketplace can also be the place where a variety of utterances is created. Particularly in 
this research, the data are not only the utterances in buying and selling transactions or bargaining activities, but the statements in exchanging opinions regarding the negative impacts of COVID-19 shared when the transaction takes place are also analyzed. The COVID-19 affects the selling and purchasing power so that the utterances will also show a different context.

Based on that, this research aims to provide an overview of the types and functions of the speech act of Tionghoa community members speaking Hokkien and in the Indonesian language used by non-Tionghoa community members in traditional markets in Medan during the COVID-19 Pandemic. This objective distinguishes this research from previous research: marketplaces are places where buying and selling transactions are found, and other interactions are found. And, this research is focused on illocutionary speech act with various types and functions as consideration.

\section{METHOD}

This research conducted direct observation (field research) with a non-participation observation technique. This research employed the descriptive-qualitative method. This method sees the reality of an individual or society as the primary data and the determiner in the study (Bungin, 2008). This research describes social interaction in buying and selling transactions and other exchanges of people in traditional markets in Medan by employing the descriptive method.

There were five traditional markets used to obtain the data, such as Pusat Pasar, Beruang, Setiabudi, Ramai, Petisah, and Cemara traditional markets. The consideration of choosing those markets is those markets are located in Medan highways and represent the various society in Medan that come for transactions, mainly to obtain the utterances of Tionghoa community members speaking in Hokkien.

Conversations or the utterances of the seller and customer as the speaker and the listener become the primary data collected by observation and taking note method. Still, the researcher does not actively participate in the conversation. The collection process is used by considering obtaining the data as naturally as possible (Sudaryanto, 2015); however, the observation method enables the researcher to understand the context and take notes of important things in the data.

Forty-eight respondents from various ethnicities were obtained, with $1: 3$ as the ratio of Tionghoa and non-Tionghoa community members using the purposive random sampling technique. The data collection was conducted using the health protocols from July to September 2020. The result obtained was classified based on the types and functions of the speech act using Sudaryanto's determinant-sorting technique (Putri \& Zulaeha, 2020). The data were analyzed based on Austin and Searle speech act theory 
(Bingtang, 2015). The data classification obtained was analyzed and described with words and the table (Mahsun, 2005).

\section{FINDINGS AND DISCUSSION}

Based on five types of speech acts and their functions according to Austin (1962) and John R. Searle (1969) theories in (Rahardi, 2009a) in both Chinese and non-Chinese communities, there were five types of speech acts found in the data. Namely, directive speech acts (DS), assertive speech acts (AS), commissive speech acts, (CS), expressive speech acts (ES) and declarative speech acts (DCS). With the number of comparisons of respondents and the speech obtained, it is more dominant in the non-Chinese community.

The results of the speech acts and the functions obtained from traditional markets in Medan are not limited to transactions - speech between buyers and sellers. However, this study also analyzed existing conditions because the transactions occurred during the COVID-19 Pandemic. The manifestation of the speech acts can be seen in tables 1 and 2 below.

Table 1:

The Form of Chinese Community Speech in Medan Traditional Market

\begin{tabular}{|l|l|l|}
\hline Types & Functions & Total \\
\hline Directive (DS) & Asking for price & 4 \\
& Asking for goods availability & 4 \\
& Asking for goods condition & 1 \\
& Commanding & 10 \\
& Bidding & 4 \\
\hline Assertive (TS) & Stating the price & 3 \\
& Expressing an opinion & 1 \\
& Describing & 3 \\
& Ensuring & 4 \\
& Asserting & 1 \\
& Complaining & 1 \\
& Informing & 7 \\
\hline Commissive (CS) & Decline the price proposed & 2 \\
& Agreeing the price & 2 \\
& Approving the goods offered & 2 \\
& Agreed with the opinion & 1 \\
& Agreed to provide services & 2 \\
& Offering goods & 2 \\
\hline Expressive (ES) & Sad & 1 \\
& Gratitude & 3 \\
\hline Declarative (DCS) & Resignation & 1 \\
\hline Total & & 60 \\
\hline
\end{tabular}


Table 2:

The Form of Non - Chinese Community Speech in Medan Traditional Market

\begin{tabular}{|l|l|l|}
\hline Types & Function & Total \\
\hline Directive (DS) & Asking for price & 6 \\
& Asking for goods availability & 4 \\
& Asking for goods condition & 4 \\
& Bidding & 8 \\
& Commanding & 7 \\
& Suggesting & 1 \\
\hline Assertive (TS) & Expressing an opinion & 1 \\
& Stating the price & 6 \\
& Ensuring & 5 \\
& Describing & 8 \\
& Informing & 5 \\
& Reasurring & 2 \\
& Complaining & 5 \\
\hline Commissive (CS) & Agreed with the price & 2 \\
& Agreed with the service & 2 \\
& Agreed with the opinion & 4 \\
& Decline the price & 5 \\
& Decline the goods & 4 \\
& Offering the goods & 5 \\
& Offering the service & 1 \\
& Predicting & 1 \\
\hline Expressive (ES) & Gratitude & 4 \\
& Sad & 1 \\
\hline Declarative (DCS) & Resignation & 1 \\
\hline Total & & 92 \\
\hline & & \\
& & \\
& & \\
& & \\
& & \\
& & \\
& & \\
& &
\end{tabular}

1. Speech Acts Variety of Chinese and Non-Chinese Community in Medan Traditional Market

\section{a. Directive Speech Act}

A directive speech act is a form of speech intended by the speaker to influence the addressee to carry out the actions they want (Rahardi, 2009). According to Leech (Chaer \& Agustina, 2004), the structure of DS is to inform, state, strengthen, suspect, complain, and tell. Based on data, the form of directive speech acts (TD) obtained in Chinese (C) and Non-Chinese (NC) communities is asking for prices, requesting for goods, asking about conditions, bidding on costs, and ordering. The following data can see the form of DS: 


\section{Data 1}

Buyer

: Hua, itu rak handuk kuice lui?

How much is the towel rack?

Seller : Seratus lima belas.

: One hundred and fifteen.

Data 2

Buyer

: Ikan kalau tiga kilo berapa?

: How much (money) three kilos of fish?

Seller

: Kali Sembilan belas aja bu, lima puluh tujuh.

: Only nineteen thousand ma'am, so it's fifty-seven.

Data 1 and 2 indicated that the speech from the buyer is a directive act in which forms of 'asking the price'. This situation is indicated by the word kuice lui which means "what price" spoken by Chinese buyers and the word "how much" talked by non-Chinese buyers, which means how much the item's price. This finding is also supported by the responses of the two sellers stating the cost of the item in question. Asking is one of the functions classified in DS based on the form of DS according to Leech Nasution \& Ayuningtias, 2020).

\section{Data 3}

Buyer

: Ko a, u be gina e ko bo a?

\section{: Mister, are there any children's pants?}

Seller : $\quad$ U, teng apa te?

Data 4

: Yes, do you want long or short?

Buyer

: Nomornya ada yang besar pak? empat puluh apa empat satu.

Seller

: Is there any big size, sir? Forty or fourty one.

: Ada ni.

: Yes, here.

Data 3 above showed the speech of Chinese buyers belonging to DS asking about an item being sought, represented by the words $u$ and $b o$. $U$ means "there", bo means "not/what". If used in an interrogative sentence, the terms $u$ and bo change the meaning to "whether" followed by the object or thing being asked. And in data 4, the buyer asked about the sandal size of they wanted to buy. 


\section{Data 5}

Buyer

Seller

Data 6

Buyer

Seller
: Jadi, sengli uw bo?

So, how about your shop?

: Sepi la, buka dasar aja belum.

It's too quiet, we haven't earned the first transaction.

\section{: Udah mulai rame pasar ya pak ya? \\ The market is starting to get crowded, isn't it?}

: Ha a, rame, itu daya beli udah ada.

Well, it is, the customers' purchasing power is getting better.

Data 5 and 6 are a form of directive speech that functions to inquire about the state of sales during the COVID-19 pandemic, which the buyers spoke about during the transaction. Then both sellers respond according to the questions posed by the buyers and state the condition of their business.

\section{Data 7}

Buyer

\section{: Jadi bo kao liao la itu a?}

Can't the price get any discount?

Seller

: Bo kao liao, net liao. (It can't, the price is fixed.)

Data 8

Buyer

: Jadi tiga puluh ya?

So, I'd take it for thirty. Deal?

Seller

$$
\text { : Jangan cinta. Jangan. (No, please don't.) }
$$

The speech conveyed by the buyers in data 7 and 8 showed that the speech is classified as DS of bidding the price. The speech conveyed by the buyers in data 7 and 8 showed that the speech is classified as DS of bidding the price. The sentence bo kao liao indicates this finding means "can the price be less". And the response speech of the furniture seller's is refused the offer or price reduction from the buyer. Whereas in data 8 , buyers who have calculated the total shopping price immediately say their bid price, the seller also rejects this.

\section{Data 9}

Buyer : Ob ane a, lu ho wa kua, pi e ancua e?

Please show me then, which one is the cheap one?

Seller $\quad$ : pi e ini lob $i$. (Yang murah seperti ini bu)

Data 10

This is the cheap one.

Buyer

: Tiga kilo ya. Gak usah dipotong-potong, nanti aku yang motong.

I'll take 3 kilograms of it. Just let it be, I'll cut it by myself later.

Seller

$$
\text { : Ikan kepalanya mau? }
$$

Do you want the fish head? 
The directive speech act of commanding in the buying and selling interactions in Medan traditional markets are dominated by the buyers because buyers come to look for what they want and need. Therefore, in that process, some sentences command the seller to give what the buyer wants, as in data 9 and 10. In data 9, lu bo wa kua, which in this context is clear an order to show the goods to the buyer. And in data 10, it is clear that the buyer orders the seller not to cut the fish. Both sellers approved the order even though it did not use the implied sentence.

\section{b. Assertive Speech Act}

'Assertive' speech act is a form of speech that binds the speaker to the truth of the preposition in the form of speech (Rahardi, 2009a). Stating, proposing, bragging, complaining, expressing opinions, and reporting are functions of AS according to Leech ( Sihotang, 2018).

In this research, the AS found in the Chinese community were in the form of telling, stating, confirming, deciding, and explaining. Meanwhile, in the non-Chinese community, AS was found, namely explaining, stating prices, expressing opinions, confirming, informing, and convincing. This can be seen in the following data:

\section{Data 11}

Buyer : Ko, a. u cui tahu o a? sui o a? Sir, is there any soya? Is it fresh?

Seller : U a. sui a.

Yes, it is. It's fresh.

Data 12

Buyer : COVID ni berdampak ga? Parah?

Seller Does COVID have any impact? Is it awful? : Dampak la bu. Yes, it does.

Data 11 and 12 showed that the seller's response speech is classified as 'telling'. In data 11 case, the buyer knows the seller means telling them they own or sell fresh tofu water. And in data 12, sellers intend to inform that the COVID-19 Pandemic impacts their sales.

\section{Data 13}

Buyer

: Kalau pak hang kiao li?

What about the other brand?

Seller

: Oh, itu yang hamik lo Phylia, tapi dia bukan aluminium a, dia besi putih yang cat ane uw o, tapi uw hijau, uw pink la ie plastic pinggir-pinggir, tapi bisa sesan, itu murah pekban tun aja. Tapi dia bisa sesan punya. 
There is Phylia but it's not aluminum. It's made from painted white cast iron, it has a green and pink color variant. The green part of the edge is made from plastic. But it can rust, the price is lower - eighty thousand rupiahs. But it can disintegrate.

\section{Data 14}

Buyer

: Eh, covid rame gak, jualan?

What about the sales during covid?

Seller $\quad$ : Sepi kali pun.... Sepi jualan gara-gara COVID ni. The market is quiet. There is only a few sales because of COVID

Based on the conversation data above, on data 13 and 14, the words from sellers who are categorized as AS have the function of explaining, namely in data 13 , sellers explain the condition of other brands that the buyer asks. In data 14, the seller explained that the COVID-19 Pandemic dropped the sales conditions. When I collected the data, Medan's government urged citizens to reduce the intensity of outside activities. Hence there would be fewer buyers who came directly to the market.

\section{Data 15}

Buyer : Ko a, u be gina e ko bo a?

Sir, do you sell pants for kids?

Seller : Kui hoi e gina?

How old is he?

Buyer : Cap hoi gina, ko.

10 years old, sir.

Data 16

Seller

: Gak banyak-banyak untungnya ini. Sikit-sikit nya itu. The profit is not much. Only a little.

Buyer : Udah botul-botul do? Is it the actual price?

Seller : Botul-botul. Botul-botul do. Yes, it is. It is.

In data 15 , the speech from the seller is categorized as a form of ensuring. The seller of children's clothing guarantees the buyer's child's age because different ages mean different sizes. Whereas in data 16, sellers and buyers use Mandailing language to communicate. Powerful speech of ensuring is spoken by the buyer in which the buyer intends to ensure that the price of fruit offered by the seller is the actual cost / not raised. And the seller also responded with "Botul-botul. Botul-botul do" repeatedly to convince buyers. 


\section{Data 17}

\begin{tabular}{|c|c|}
\hline Buyer & $\begin{array}{l}\text { : Kui ce lui a ko a? } \\
\text { How much is it, sir? }\end{array}$ \\
\hline Seller & $\begin{array}{l}\text { Tiok pak go ceng. } \\
\text { A hundred and fifty thousand }\end{array}$ \\
\hline \multicolumn{2}{|c|}{ Data 18} \\
\hline Buyer & $\begin{array}{l}\text { : Cabenya berapa? } \\
\text { How much does the chili cost? }\end{array}$ \\
\hline Seller & $\begin{array}{l}\text { : Cabenya empat ribu. } \\
\text { It is four thousand. }\end{array}$ \\
\hline
\end{tabular}

Data 17 and 18 that the seller spoke were the 'stating' form of AS. In this case, the buyers ask the price of the item being sought, and the responses of the two sellers are classified as 'stating', namely stating the cost of the goods.

\section{Data 19 \\ Buyer : Jadi, Sengli uw bo? \\ So, how about the shop? \\ Seller : : Sepi la, buka dasar aja belum. \\ It's too quiet. We haven't earned the first transaction. \\ Buyer : Kok ane kelian. \\ How pity. \\ Seller : Parah, luar biasa. \\ It is incredibly severe}

Data 20

Buyer

: Mahal jipang ya bang.

Jipang is costly, isn't it, sir?

Seller : Yang organik, iya.

Yes, the organic one.

In data 19, shopping buyers asked the seller about their business condition during the COVID-19 Pandemic. The seller response showed a complaint that the lack of buyer visits the store, even goods with relatively low prices did not sell well because, during the COVID-19 Pandemic, all people had to reduce activities outside. Besides, many Medan citizen has switched to shopping by an online store. The speech belongs to AS' expressing an opinion.

In data 20, buyers expressed their opinion about the price of a vegetable, which turned out to be more expensive than others. It is also agreed by the seller's statement that the vegetables chosen by the buyers are more costly than non-organic vegetables. 
Data 21

Seller

: Jangan. Nanas gak bisa kakak. Aku nanggung kalau nanas.

No. I can't give you the pineapple for that price.

Buyer : Jadi berapa?

So, how much is it?

Seller

: Tiga lima semua. Dua lima tambah sepuluh. Jangan cintaku. Kalau nanas ampun nandro. Cek cek tanya di

bawah itu nanti. Kemahalan, kembalilah lagi.

It is thirty five. Twenty five plus ten. Please, don't. I can't give you the pineapple. You can check the other shops. You can come back after you do the price check.

In data 21, the seller's speech convinced the buyer he could not reduce the price of the fruit, and he convinced the buyer by checking with other stores and returning it if the cost of the fruit was higher.

Data 22

Buyer : Bo kao liao a?

Can't the price have any discount?

Seller

\section{: Seratus sepuluh netnya.}

It is a hundred and ten for the net price.

The seller's speech on data 22 indicated AS of 'confirming'. In this case, the seller insists that the price bid by the buyer was unacceptable. In the sentence "seratus sepulub netnya", the word "net" in English refers to the net sales price or, in standard terms, refers to the fixed price, in which the buyer cannot negotiate anymore.

\section{Data 23 \\ Seller : Pi e ini lobi. \\ This one is the cheap one. \\ Buyer : Ob ini lai hio. ada kui e li? \\ I see. What about the expensive one? \\ Seller : Kui e ini.. ie sia e kek gini e. \\ This one is more expensive. This is how it sounds like. \\ Buyer : Oh ane a, oh.. wa e kia be hiao tik tok e la, wa be pi e \\ ho liao la ya dek ya. \\ I see. But my child is not good at using toy gun, I'll have the cheap one.}

In data 23 , the buyer intends to find toys for his child. The seller offers several types of toys and their prices. After looking at the difference in price and quality of toys, the buyer decided to buy a toy gun at a low price because it adjusted the age of his young child which was not too capable of 
playing with a gun toy. This is indicated by the sentence "saya beli yang murah saja ya dek". The buyer's speech is classified as AS of 'deciding'.

Data 24

Seller : Sepi jualan gara-gara covid ni. The shop is too quiet due to covid.

Buyer : Yaudah, sabar ya. Well, be patient, okay.

The context in data 24 is the sellers complain about the lack of buyers who come during the COVID-19 Pandemic because many buyers have switched to online purchases. Buyers try to understand the seller's complaints and provide suggestions to be more patient with these conditions. This suggestion arises because the seller and the buyer already know each other. The buyer's speech is classified in the AS of 'suggesting'.

\section{c. Commissive Speech Act}

The manifestation of commissive speech acts expresses specific promises or offers (Rahardi, 2009). The forms of commissive speech act found in the Chinese community in the Medan traditional market consist of offering goods, rejecting prices, agreeing on prices, agreeing with opinions, approving goods being delivered and approving services. In the non-Chinese community, apart from finding CS of offering goods, rejecting prices, agreeing with prices, agreeing with opinions, approving goods being delivered and approving services, I also found CS of leaving goods presented and predicting.

\section{Data 25}

Buyer

: Lu bo wa qian lam e lo byo.

Give me the one with bright blue color.

Seller : Nab uw ini nah, kua e gam bo?

Data 26

Seller : Pilih, pilih pilih. Ini la kam ambil. Cantik.

Yes, I have it. Have a look, is it okay?

Come, come, come. Take this one. It is pretty.

Buyer : Gak mau, itu gak merah.

No, I don't want to. It's not red.

Seller $\quad$ : Kok gak ini lah. Apalagi jeruk madu.. aduh paling cantik sedunia.

Then take this one. You can also take the tangerine.. this one is the prettiest above all.

Buyer $\quad$ : Rasa dulu lab.

I'll have a bite.

Seller : : Jangan lab, kau jangan gitu kau sayang.

Don't. Please don't do that, honey. 


\section{: Nah, ambil satu lagi ini.}

Take this one for more.

Buyer : Enggak, enggak, enggak. Enam biji aja.

No, no, no. Just take six of them.

Data 25 and 26 above showed CS of 'offering goods' delivered by the seller. These data are indicated in the sentence 'kua e gam bo' by the seller of children's clothing, which means "lihatlah ini terlebih dahulu kira-kira cocok atau tidak" intended offer is for the buyer to see or check the goods offered or shown by the seller. Data 22 also showed 'offering' made several times by the seller to the buyer even though there was rejection, but the seller still tried to offer his wares. This situation is commonplace because the offering is standard for sellers; hence, their goods can sell well.

Data 27

Buyer

: Ob Corona, be yang sesan pun bo yao kin.

During this pandemic I can have the easily rust one. No problem.

Seller

: Ya. Habis corona baru beli baru.

Yes, buy a new one after the pandemic.

Data 28

Buyer

: Bu, gimana Selleran selama corona ini kita?

How about the sales during the pandemic?

Seller

: Ya.. bekurang, ku akui bekurang, tapi nggak drastis.

It is reduced, I admit it, but it's not too drastic.

Buyer

\section{: Iya, karena sembako ya termasuk apa ya kan.}

Yes, because groceries are the primary needs.

In data 27 , the furniture seller agreed with the opinion expressed by the buyer that during a pandemic, it is felt quite difficult; hence buying goods with low quality helps reduce excess costs. At the same time, they were waiting for the Pandemic to end and rearrange finances to believe in better things.

In data 28 , the buyer agreed with the opinion expressed by the seller. Buyers are shopping at grocery sellers while asking about the condition of their business during the COVID-19 Pandemic. The seller responds that there is a reduction in sales or a decrease in people's purchasing power directly to the market even though the sales have not decreased drastically. And this was approved by the buyer because groceries are a basic need, so there are still many people looking for them, but people who shop directly at the market are reduced due to the COVID-19 Pandemic. There are calls to reduce activities outside. The two speeches belong to CS of 'agreeing'. 
Data 29

Seller

: Nab un ini nah, kua e gam bo?

Yes, we have it, have a look. Is it good?

Buyer

: Oh..e la, e gam liao la ini.

Data 30

Oh, yes. This one is okay.

Buyer

: Tabunya empat ya, kasi yang tebel-tebel ya.

Seller

I'll take four tofu. Give me the thick one.

: Iya.

Okay.

In data, 29 sellers offered and showed the goods beforehand, and the buyer agreed to purchase the goods offered. Whereas in data 30, by saying the word "iya", the seller agreed to provide the goods requested by the buyer. Hence the speech on data 30 and 31 are categorized as CS of 'approving' the goods offered by the seller and 'agreeing' to provide the requested goods.

\section{Data 31}

Seller

: Be kiam a, be kiam, sit ke liao.

I can't give you any more discounts. I can't. The price is fixed

Buyer

: Hyo oke la. Ho wa ce kai lo ya.

Okay. Give me one.

Data 32

Buyer

: Gak lapan belas? (tidak delapan belas?)

Is it not eighteen rupiah?

Seller

\section{: Yauda gak apa apa.}

Fine, I'll let you have it

Data 31 and 32 showed that buyers and sellers could make price agreements. In data 32, previously, the buyer had offered to reduce the price (bidding) but was rejected by the seller. Because the buyer felt that the price shown was acceptable, the buyer then agreed. Whereas in data 33, the buyer also made a price reduction offered (bidding) and was immediately approved by the seller because the buyer was one of his customers. Hence, in data 32, the buyer's and seller's speech in data 33 are categorized as CS of 'agreeing on the price'.

Data 33

Buyer : E.. Brokoli ho wa cekai. Ha ini ko a, kimkua e kak wo ciet cepoa o?

Give me one broccoli. This one too, can you give me a half of this pumpkin for me?

Seller

: e a ci a.

Yes, I can. 
Data 34

Seller

: Ikan kepalanya mau?

Do you want the fish head?

Buyer : : Males la bersibinnya lagi.

I'm too lazy to clean it up.

Seller : Tapi kami bersibin, potong-potongi.

Buyer : Iya? bolehlah.

Really? Okay, then.

In data 33, speech by the vegetable seller and data 34 , speech by the fish buyers, were 'agreeing' speech acts. However, the difference is that in data 34, the vegetable sellers agreed to provide the services requested by the buyers. In contrast, in data 35 , the buyers agreed to be provided with assistance by the fish sellers.

\section{Data 35}

Buyer : Jadi bo kao liao la itu?

So, the price can't have any discount?

Seller : Bo kao liao, net liao.

Data 36

No, it can't. The price is fixed.

Buyer

: Gak kurang lagi harganya ini?

Can't the price get any discount?

Seller

: Gak banyak-banyak untungnya ini. Sikit-sikit nya itu.

I don't take a lot of profit from this sale. It's only a few.

In data 36, the furniture seller used a speech that directly rejected the buyer's offer. In contrast, in data 37 , the fruit seller used a speech that indirectly denies the bid of price reduction requested by the buyer. Hence the speech is classified as CS of refusing a price.

\section{Data 37}

Seller : : Pilih, pilih pilih. Ini la kam ambil. Cantik.

Come, come, come. Take this one. This one is pretty.

Buyer : Gak mau, itu gak merah.

No, I don't want to. It's not red.

Buyer : Nah, ambil satu lagi ini.

Here, I'll have this one for more.

Buyer

: Enggak, enggak enggak. Enam biji aja.

No, no, no. Just take six of them.

In data 37, the buyer has refused to accept the goods offered by the seller. The rejection was seen in the words "Gak mau" (I don't want it) and 
the words "enggak, enggak enggak," the buyer repeatedly uttered. Hence the buyer's speech is categorized as CS refusing the offered item.

\section{Data 38}

Buyer : Ini berapa yang ini dod? Nab ini.

How much does this cost? This one.

Seller $\quad:$, ini.

$\mathrm{Oh}$, this one...

Buyer : Gedean, gedean coba, nengok. It's bigger, look at it.

Seller : : Aa.. sepulub ribu. Udab ini nah, tiga belas ribu aja tante. Murah aja.

Oh... It's ten thousand. Just take this one here, It's only thirteen thousand. It's cheap.

Buyer : Yauda lah. kayaknya cantik ini gulanya.

Fine. I think this brown sugar is prettier.

Seller : Iya, agak bagus dia.

Yes, it's better.

The context of the above speech is a woman who wants to buy brown sugar. When choosing an item, she pointed to a large brown sugar. The speech of "yauda lah. kayaknya cantik ini gulanya" belongs to TK of 'predicting'. The word "kayaknya", which means 'likely, and "agak", which means 'a little' are marker words that express predictions of something. In this case, the buyer predicted that the brown sugar she chose was of good quality. The seller's speech also supported this data.

\section{d. Expressive Speech Act}

Expressive speech acts (ES) are speech forms that express or show a speaker's psychological attitude towards certain situations (Rahardi, 2009). In the speech of the Chinese community in Medan traditional markets, expressive speech acts of gratitude and sadness are identified. Explicit speech acts of gratitude remember the definitive speech act of non-Chinese communities in Medan traditional markets. The following is the discussion:

\section{Data 39}

Buyer : Ai be noban e la. lu bo wa cekai ya.

I'll have the one that costs twenty thousand. Give me one.

Seller : Ya, oke. Kamsiaya i.

Data 40

Yes, okay. Thank you, ma'am.

Buyer : Nengok dulu, uangnya hitung dulu. Keknya pas sih, dod. Coba liat dulu.

Please have a look, count the money first. I think the amount of the money is right. Check it. 
Seller

\section{: Pas. Makasi banyak \\ Yes, it's right. Thank you very much.}

In data 39 and 40, the expressive speech act of gratitude can be seen clearly from the words spoken by the seller. In the data, the children's toy seller uses "Kamsia" in Hokkien, which means thank you, and for non-Chinese vegetable-sellers use the word "makasib banyak", which means thank you very much.

\section{Data 41}

Buyer

: Jadi, Sengli uw bo?

So, how about your shop?

Seller

: Sepi la, buka dasar aja belum.

Data 42 It's too quiet, we haven't earned the first transaction.

\section{Buyer \\ Yang dapat bantuan, dapat bantuan. Kek awak yang gak dapat bantuan ini nangis la bu. \\ They who gets the aid, gets the aid. For me who don't get it, I can only grieve, ma'am. \\ Seller \\ : Ada bantuan, bantuan lima kilo surub duduk di rumah, anaknya sepuluh.}

There is a food aid. The aid is only five kilograms and we are ordered to stay at home while we have ten children to feed.

In data 41, buyers asked about the business conditions of the furniture seller during the COVID-19 Pandemic. The response of the seller's speech and expression shows sadness. When the interaction took place, it was 3 p.m., but no buyers had arrived.

The context of the speech in data 42 is that the buyer previously asked the seller how their sales were during the COVID-19 Pandemic. And the seller's response showed sadness. This can be clearly seen in the sentence "Kek awak yang gak dapat bantuan ini nangis la bu" (like me, who didn't get the gov. aid, it is very sad mam). Sellers feel they deserve to get the aid from the government that was distributed specifically during the COVID-19 Pandemic for underprivileged people. However, the seller did not get this aid. Therefore he felt sad and had to continue to open the business during the COVID-19 Pandemic to meet the family needs.

\section{e. Declarative Speech Act}

Declarative speech acts function to connect the contents of the speech with reality. In this research, only one DCS was found in this research, which served resignedly to the situation. 
Data 43

Buyer

Seller

Data 44

Seller

Buyer

Seller

: Oh Corona, be yang sesan pun bo yao kin.

During this pandemic I can have the easily rust one. No problem

: Habis corona baru beli baru.

Buy a new one after the pandemic.

: Kalo berdiam di rumah aja pun siapa yang ngasi makan bu.

If I stay at home, no one will feed my family.

: Ha itu dia.

Yes, that's it.

: Udah dari rumah bismillah lillahi taala, gitu aja bu. I pray everytime I leave my house, just like that.

The context of the speech in data 43 is a buyer who wanted to buy a towel rack and has made an offer, but the seller refused. The buyer felt that the price of the desired item was relatively high, so he decided to buy another article of lower quality than the previous item. The speech of "ob Corona, be yang sesan pun bo yao kin" showed the buyers' resignation to the situation. So that during the Covid-19 Pandemic, buying goods of low quality was not a problem.

Meanwhile, the context of the speech in data 44 is that the buyer asked about the sales of the chicken seller during the COVID-19 Pandemic and one of the responses from the seller's speech showed a DCS of resignation to the situation. This speech marked in the seller's speech which stated "udah dari rumah bismillah lillahi taala, gitu aja bu" there is the sentence "bismillah lillabi taala" which in Islam "bismilllab" (in the name of Allah) the activity is submitted to the Creator, namely Allah SWT.

\section{CONCLUSION}

Based on the data and analysis above, the form of speech acts of the Chinese community in Medan traditional markets is applying the speech act theory proposed by Searle, which found five forms of speech acts based on this theory. The five forms of speech acts found are directive speech acts, assertive speech acts, commissive speech acts, expressive speech acts, and declarative speech acts.

The directive speech act is the dominant speech act found in the transaction-speech interaction and the communication between the sellerbuyer when they ask and respond to each other about their conditions during the COVID-19 Pandemic because the directive speech acts have an influencing element to the addressee, in this case, the buyers act dominantly in influencing the seller to do what they want. This characteristic is related to one of the language characteristics as a social act. In other words, language 
can be used to influence even control a person's mental state (Triana \& Zamzani, 2019).

It can be seen in the directive speech act that the dominant function of commanding is found in the Chinese community, and the chief process of bidding is located in the non-Chinese community. Meanwhile, declarative speech acts are the fewest speech acts that only serve to express resignation to the situation due to COVID-19.

The ordering directive speech act is dominantly found in Tionghoa speakers, and this relates to the character of the majority of Tionghoa community members in Medan, which is straightforward. In this case, they give orders directly towards what they need and find. Meanwhile, in the nonTionghoa community, the utterances refer more to one of buying and selling laws, dominated by bargaining utterances.

The interaction of Tionghoa and non-Tionghoa speakers in Medan traditional markets shows interactions or utterances in buying and selling activities and expresses opinions regarding the same condition experienced together; the COVID-19 Pandemic. Therefore, the stated views make the statements more varied, yet the purpose of both the seller and customer is still achieved.

This study is expected to contribute in adding information regarding a social phenomenon in pragmatics, especially in the types and functions of utterances in daily conversations which are frequently used by the society in Medan in traditional markets, and contribute to the variety of vernacular languages in this case, the Hokkien language.

\section{ACKNOWLEDGEMENT}

This research was funded by Lembaga Penelitian TALENTA University of Sumatera Utara number 4142/UN5.1.R/PPM/2020, $27^{\text {th }}$ of April 2020 .

\section{REFERENCES}

Anagaw, A. (2019). An Analysis of Speech Act in Transactional Discourse : Bati Market in Focus Asemach Anagaw *. 4(1), 10-18.

Astuti, S. P. (2019). Tuturan Langsung dan Tidak Langsung antara Penjual dan Pembeli di Pasar Tradisional Semarang. Nusa: Jurnal Ilmu Bahasa Dan Sastra, 14(2), 239. https://doi.org/10.14710/nusa.14.2.239-252

Bahing, -, Emzir, -, \& Rafli, Z. (2018). English Speech Acts of Illocutionary Force in Class Interaction. Advances in Language and Literary Studies, 9(3), 113. https://doi.org/10.7575/aiac.alls.v.9n.3p.113

Bingtang, S. (2015). An Analysis on Light in August from the Perspective of Speech Act Theory. Journal of Xi'an Aeronautical Universiry, 33.

Bungin, B. (2008). Analisis Data Penelitian Kualitatif. Jakarta: Raja Grafindo 
Persada.

Kamus Besar Bahasa Indonesia (KBBI). (n.d.). Retrieved from https://www.kbbi.web.id/pasar

Ludwig, S., \& de Ruyter, K. (2016). Decoding social media speak: developing a speech act theory research agenda. Journal of Consumer Marketing, 33(2), 124-134. https://doi.org/10.1108/JCM-04-2015-1405

Mahsun. (2005). Metode Penelitian Bahasa. Jakarta: PT Raja Grafindo Persada.

Nasution, V. A., \& Ayuningtias, N. (2020). Speech Act Variety of Traders in Traditional Markets during the COVID- 19 Pandemic in Medan TALENTA Conference Series Speech Act V ariety of Traders in Traditional Markets during the COVID- 19 Pandemic in Medan. 3(4). https://doi.org/10.32734/lwsa.v3i4.1150

Nasution, V. A., \& Ayuningtyas, N. (2020). the Language Choice of Chinese Community in Medan: a Sociolinguistics Study. JOALL (Journal of Applied Linguistics \& Literature), 5(1), 11-25. https://doi.org/10.33369/joall.v5i1.9063

Padmayanti, D. ., Wedhanti, N. ., \& Agustini, D. A. . (2018). an Analysis of Sellers' and Buyers' Speech Acts in Daily Transactional Communication At Banyuasri Traditional Market in Buleleng. Language and Education Journal Undiksha, 1(2), 89-99. https://doi.org/10.23887/leju.v1i2.20262

Purnamentari, L. Y., Suandi, I. N., \& Wisudariani, N. M. R. (2019). Analisis Jenis, Bentuk, Dan Fungsi Tindak Tutur Berita Utama Pada Koran Bali Post. Jurnal Pendidikan Bahasa Dan Sastra Indonesia Undiksha, 8(1), 13-22. https://doi.org/10.23887/jjpbs.v8i1.20239

Putri, N. I., \& Zulaeha, I. (2020). Tindak Tutur Direktif Humanis Langsung dalam Film "Anak Negeri Kisah Masa Kecil Ganjar Pranowo." Indonesian Language Education and Literature, 6(1), 58. https://doi.org/10.24235/ileal.v6i1.4942

Rahardi, K. (2009a). Sosiopragmatik. Yogyakarta: PT. Gelora Aksara Pratama.

Rahardi, K. (2009b). Sosiopragmatik (W. Hardani, Ed.). Yogyakarta.

Sagita, V. R., \& Setiawan, T. (2020). Tindak Tutur Ilokusi Ridwan Kamil dalam Talkshow Insight di CNN Indonesia. Lensa: Kajian Kebahasaan, Kesusastraan, Dan Budaya, 9(2), 187.

Sari, R. P., Sofyan, A., \& Rochiyati S., A. E. (2020). Tindak Tutur Ilokusi Dalam Interaksi Jual Beli Di Pasar Tempurejo, Jember. SEMIOTIKA: Jurnal Ilmu Sastra Dan Linguistik, 21(2), 114. https://doi.org/10.19184/semiotika.v21i2.16551

Sariasih, Y. (2017). Analisis Tindak Tutur Bahasa Komering Desa Tanjung Baru Kecamatan Tanjung Lubuk Kabupaten Ogan Komering Ilir. Jurnal 
Bindo Sastra, 1(2), 79. https://doi.org/10.32502/jbs.v1i2.694

Setiawan, E. (2018). Tionghoa Medan, Komunitas Paling Kontroversial di Indonesia.

Jakarta Barat: PT Buku Pintar Indonesia.

Sihotang, R. (2018). DI PASAR TRADISIONAL AKSARA MEDAN The Various Speech Acts of Social Interactions in Tradisional Market at Medan Market.

Sudaryanto. (2015). Metode dan Teknik Analisis Bahasa. Yogyakarta: Duta Wacana University.

Surip, M. (2019). Ragam Tindak Tutur Interaksi Sosial di Pasar Tradisional Sukaramai Medan. from https://www.researchgate.net/publication/335109665_RAGAM_TIN DAK_TUTUR_INTERAKSI_SOSIAL_DI_PASAR_TRADISIONA L_SUKARAMAI_MEDAN

Triana, P. M., \& Zamzani. (2019). Power Representation in the Grammatical Form of Teacher's Speech Acts in Indonesian Language Learning. Lensa: Kajian Kebahasaan, Kesusastraan, Dan Budaya, 9(1), 77.

Umaroh, L. (n.d.). D ominasi Ilokusi dan Perlokusi dalam Transaksi Jual Beli. 7, 21-34.

Wahdian, A. (2016). Tindak Tutur Dalam Transaksi Jual Beli Ikan di Pasar Keppo. Wacana Didaktika, 4(1), 1-15. https://doi.org/10.31102/wacanadidaktika.4.1.1-15

Ziaulhaq, Z. (2017). Ragam Bahasa Dan Strategi Tindak Tutur Pedagang Asongan Di Terminal Purabaya Kota Surabaya. Lingua Franca:Jurnal Bahasa, Sastra, Dan Pengajarannya, 1(2), 123-134. https://doi.org/10.30651/lf.v1i2.566 